\title{
CLCF1 wt Allele
}

National Cancer Institute

\section{Source}

National Cancer Institute. CLCF1 wt Allele. NCI Thesaurus. Code C99760.

Human CLCF1 wild-type allele is located in the vicinity of $11 \mathrm{q} 13.3$ and is approximately 10 $\mathrm{kb}$ in length. This allele, which encodes cardiotrophin-like cytokine factor 1 protein, plays a role in the regulation of both immunog lobulin production and cytokine signaling. 